\section{RECONCEPTUALIZING INDIANIZATION: \\ A STUDY OF THE ART OF THE LOCAL FEMALE DEITIES $^{1}$}

\section{Rattanaporn Poungpattana ${ }^{2}$}

\begin{abstract}
It was formerly known and agreed generally that the earliest Southeast Asian people did not create their own civilization, but adopted models from India. Accordingly, civilization in Southeast Asia is called "Indianization". Yet, there are three mains schools of thought giving different views of the characteristics of Southeast Asian civilization. While the first school, led by Coedes, points out that civilization in Southeast Asia is not so different from its Indian models, the second school, led by Wolters, suggests that Southeast Asian civilization is completely different from the Indian one due to the process called 'localization'. Compromisingly, the last school, led by Mabbett, proposes the harmonious living of the two cultures in local societies. As the debates are still uncompromised, the article offers the examination of the case study of female deities in an attempt to compromise those debates. According to the observation on the case study, it can be summed up that
\end{abstract}

\footnotetext{
${ }^{1}$ The writer would like to thank her teacher, Dr. Sunait Chutintranond, director of the Southeast Asian Studies, Chulalongkorn University, for his kindness and his patience. Without him, the paper would not have been completed.

${ }^{2}$ A Master's Degree student of Southeast Asian Studies, Chulalongkorn University.
}

Wolters and Mabbett's suggestions seem closer to the real situation, and that Southeast Asia has its own typical civilization.

\section{Introduction}

In the past, when talking about the civilizations of Southeast Asia, almost all observers, or even scholars, looking from outside the region, might have thought of the term "Indianization". What was worse was that the term might have been coined for Southeast Asia in particular.

In earlier times, almost all people thought of Southeast Asia as 'the farther India' as if the region had no identity of its own. While some Southeast Asians might have silently disagreed, it would have been in vain to openly complain: "Don't say that! we have our own cultural identity that cannot be found anywhere else even in any other Southeast Asian state."

It cannot be denied that the civilization of Southeast Asia came mainly from Indian influence. But to claim that this influence is eternal and unchangeable is to overstate the case.

For a long time, discussions on this topic have involved two questions: Whether Indian influence left in Southeast Asia is pure or not, and if not, what is the extent of Indian influence on local cultural materials.

Coedes' view that "to study Southeast Asia gives us only further knowledge of India," ${ }^{3}$ clearly shows that, in his opinion,

${ }^{3}$ Coedes. 1968. The Indianized states of Southeast Asia, p. 34. 
the two cultures, or the cultural materials of India and Southeast Asia, are alike.

After Coedes' day, more and more scholars took an interest in this topic. Later scholars who focused their attention on Southeast Asia, opposed Coedes fiercely. One might agree with Coedes if glimpsing only at the surface of those material, or at their veneer. However, Coedes' view has been debated by many other scholars. Thus, between Coedes' view which we can observe with our own eyes, and the view of many other scholars', which is completely opposed to Coedes', whose view should we believe?

The aim of this paper is to find out the answer to this question. We will look through our own eyes, before accepting the suggestions of scholars, and conduct our own analysis through a case study of local Southeast Asian goddesses.

The local goddesses I choose to analyze include Mae Phosop, the Thai and Tai ethnic groups' rice goddess; Po Nagar, the Cham's mother goddess; Wathoundaye and Mae Thauranii, the Burmese and Thai earth goddesses; and other three local deities of the Burmese, including the Golden Face, the Lady Three Times Beautiful, and the Little Lady.

The reason I choose to analyze these goddesses is that the local goddesses are representatives of what Mabbeth calls 'inferior culture', and as such received the big impact from the input of the superior culture, namely Indianization. Thus, focusing on them, we can see the relationship and level of interaction between the two cultures from the beginning of the process to the end.
In this paper, 'I will first summarize earlier scholars' debates on Indianization in Southeast Asia, relating to the two questions I have raised initially. Then, I will focus on each local goddess. In the third part, I will analyze them and present other scholars' views in order to determine whose interpretation is more credible. Finally, I will discuss why the degrees of Indian influence $1 \mathrm{eft}$ in $\mathrm{e}$ ach $\mathrm{c}$ ase a re $\mathrm{n}$ ot equal.

\section{Debates on Indianization in Southeast Asia}

All scholars have unanimously agreed that Indian influences spread into Southeast Asia and had a major impact on local cultures. However, the debates that follow still arise.

\subsection{The debate on whether Southeast Asia cultural materials resemble the Indian originals:}

Coedes' view is the c ause of this debate. Actually, he too accepts that the indigenous Southeast Asians who adopted Indian cultural materials, adapted or localized them, as he believes that "each people possessed its own local genius." 4 However, he still believes that the localized materials cannot be very different from the original ones as, "Their culture never lost the family resemblance."

\footnotetext{
${ }^{4}$ Wolters. 1982. History, Culture, and Region in Southeast Asian Perspectives, op. cit. Coedes, in p.45.

${ }^{5}$ Ibid.
} 
Coedes also views the Indian influence in Southeast Asia as a legacy with strong roots even today. He says:

Even in the countries where indigenous traditions reacted most strongly and splintered the Indian veneer; however, such was the force of the penetration of Indian culture that its legacy is far from being negligible. This legacy includes 'the system of writing', 'the virtually unchanged cosmogonic myths', 'the great epic themes of the Ramayana and Puranas', 'certain artistic formulas'...

This idea is reiterated in his other work. And it is also quoted with disapproval by Mabbett:

George Coedes has also given weight to indigenous initiative in the process and to the continuing vitality of indigenous culture; however, he sees Indianization overall as a transplant rather than a mere graft: 'Indian culture put down its roots in a new soil, and changed without losing its identity., 7

Coedes' hypothesis has not been accepted by many other scholars, including Mabbett and Wolters. They used logic to oppose the assertion and support their own novel suggestion. This logical process will be explained in the section that follows.

${ }^{6}$ Coedes. 1968. The Indianized states of Southeast Asia. p.34.

${ }^{7}$ Wolters. 1982. History, Culture, and Region in Southeast Asian Perspective.s Op. cit, Coedes in p.45.
All scholars unanimously agree that the indigenous societies of Southeast Asia had cultures of their own long before the arrival of the Indians. Even Coedes himself agrees:

The Indians were not confronted by uncultured 'savages', but on the contrary, by people endowed with a civilization that had traits in common with the civilization of pre-Aryan Indian. ${ }^{8}$

In a sense, the local earth god cults that spread throughout Monsoon Asia should be included in the civilization mentioned above by Coedes. Paul Mus, as quoted in Mabbett, has stated that in pre-Aryan India and pre-Indian Southeast Asia the [earth god] cults were alike. 9 Thus, what happened in Southeast Asia had been happening in India where "Hindu culture developed from contact between Aryans and pre-Aryans..." In other words, what happened to the cults in Southeast Asia can be explained by the following message:

These localized indigenous cults assumed more elaborate forms, adopted....and acquired universal values, without losing their essence. $^{10}$

This assertion gives credence to the idea, proposed by Mabbett and Mus in opposition to that of Coedes. In this matter, they and also Wolters believe that

${ }^{8}$ Coedes. 1968. The Indianized states of Southeast Asia. p.15.

${ }^{9}$ Mabbett. 1978. Kingship in Angkor, op. cit. Mus in p.49.

${ }^{10}$ Ibid. 
the cultures of Southeast Asia that adopted Indian influences are not so pure as claimed by Coedes, and that local essences continued to exist.

In his "Kingship in Angkor", Mabbett concludes: "Thus, an examination of the nature and extent of Indian influence suggests that it didn't drive out local traditions in any Southeast Asian Kingdom."11

However, scholars differ on the extent of Indian influence. Their differences are discussed briefly in the section that follows.

\subsection{Different ideas on the extent of Indian influence}

While Coedes sees Indian influence as still strong and not much changed, Mabbett views this matter differently. In his view, the extent of Indian influence has retreated, and "the interaction of two cultures is in a network of interdependence." $\mathrm{He}$ states, "What happened was the two orders -Indian and local, high and low -- adapted themselves into a series of complementary relationships so that they could become the heads and tails of a single coin."12

$\mathrm{He}$ also reinforces his idea by citing what B.P. Groslier and Paul Mus have suggested:

There had to be an approximate equality between giving and receiving cultures. And because of the shared s ubstratum beneath both Indian and local traditions, the former were recognized,

\footnotetext{
${ }^{11}$ Mabbett. 1978. Kingship in Angkor, p.50.

${ }^{12}$ Ibid.
}

welcomed and 'lived' without consciousness of change. ${ }^{13}$ The two levels of cultures [therefore] lived in each other and were not consciously distinguished. ${ }^{14}$

Meanwhile, though Wolters also opposes Coedes' view that 'the 'states' of Southeast Asia were continuously shaped and sustained by Indian cultural influences," his suggestion is similar to Mabbett's though not entirely the same. He claims that the local genius causes a process he calls "localization", in which "the Indian materials tended to be fractured and restated and therefore drained of their original significance ${ }^{15} \ldots$ The materials, including their words, sounds of words, book, or artifacts had to be localized in different ways before they could fit into the local complexes....and belong to a new cultural whole." ${ }^{\text {"16 }}$

However, in one way Wolters completely disagrees with Mabbett. Wolters states:

In some local statements, however, the foreign materials have retreated so completely that they seem to have disappeared, $\ldots{ }^{17}$

13 Mabbett. 1977. The Indianiazation of Southeast Asia: Reflections on the Historical sources, pp.144-145.

${ }^{14}$ Mabbett. 1978. Kingship in Angkor, p.49.

${ }^{15}$ Wolter. 1982. History, Culture, and Region in Southeast Asian Perspectives, p.52.

${ }^{16}$ Ibid.

${ }^{17}$ Wolters. 1982. History, Culture, and Region in Southeast Asian Perspectives, p.55. 
Here, one can see that the ideas of Mabbett and Wolters are dissimilar. To be able to judge the validity of these ideas, let us proceed to the case study.

\section{The specification on the case studies}

\section{Mae Phosop ${ }^{18}$}

According to Textor, the earliest Mae Phosop is shapeless as she is "Khwan", a Thai word meaning "soul". ${ }^{19}$ Her origin was as an agricultural supernatural power worshipped by Tai ethnic groups for whom rice was significant for many thousands of years. The soul (Khwan) was believed to abide in the paddy, rice, or rice shaft.

In Indianization, the formless soul (Khwan) was transformed or reified into the Indian goddess, Savadheve, who is the consort of Indra. She also got a new name, Phosop, coming from the adaptation of Savadheve into Phosavadheve, which was then inflected into Phosop.

However, there is also a male version of the rice deity. This is because in some areas the local people believed that their old supernatural being, or Khwan, was male, Pu Khwan Kao. Thus, when Indianized, the Khwan was transformed into the image of an Indian god, namely, Kuvera, who according to Hindu-Buddhist belief is considered the god of abundance. The Pali version of the Indian god's name

\footnotetext{
${ }^{18}$ The source of Mae Phosop comes mainly from an article, written by Wanna Navigamoon in the book, "Rice in Thai Arts and Cultures." See her pictures 1-8

${ }^{19}$ Textor. 1960. An Inventory of Non-Buddhist Objects in a Central Thai Village, p.418.
}

is Vessavana, and in Sanskrit it is Vaishravana. The word was inflected or localized several times into, namely, Phaisropana, then Phaisop, and eventually Phosop. Though we can see $P o$ Phosop' $\mathrm{s}$ name in some Thai literature related to agricultural rituals, Po Phosop was not so well known among the people as Mae Phosop.

Even today, the myths of Mae Phosop are varied, not only among the Tai ethnic groups, but also among the people in Thai society. Among the Tai ethnic groups, though the content of the myths of Mae Phosop is varied, the subject of the legends is alike. All are about the story of a female rice deity who, upset by the ingratitude of human beings, flees from the world of men.

On the other hand, in Thai society, the myths narrated in temples are different from the myths passed on among the common people. Some myths say that Mae Phosop was Indra's wife who wanted to help human beings. Other myths tell that she felt slighted by Buddha's ingratitude at her great kindness, and then went away.

As previously mentioned, we can see that there are many myths of this deity. She was either identified as wife of Indra or as the slighted local rice goddess, or even as the rice goddess who had met the Buddha.

An image of Mae Phosop as the Indian goddess Savadheve still remains. Her picture is found at Wat Sam Kaew, a Buddhist temple in Chum-porn province, Thailand (see also picture 1 ). In the picture she sits in the same row as the two Indian goddesses, Lakshmi, the consort of Visnu, and Sarasvati, the consort of Brahma. 
Interestingly, however, she is identified, under the picture, as Mae Phosop, not Savadheve. Moreover, her image is likely not that of an Indian goddess anymore. Sitting between Lakshmi and Sarasvati, who wear the more typical Indian style costume, Mae Phosop herself wears a local Thai-style headdress and costume with rice shafts in her hand.

In some pictures, Mae Phosop is shown riding a fish. These can be understood by the fact that some myths tell that when Mae Phosop, the rice-keeper deity, felt slighted by the ingratitude of people, she left the village, and the suffering peasants could successfully meet her again with a fish's assistance (Picture 2).

To conclude, it can be said that the differences in Mae Phosop's image came from the different myths of Mae Phosop told since early times. In the local myth, Mae Phosop was either a local female, or male, deity (Pictures4-5). Meanwhile, Mae Phosop in temples is described as Savadheve, a wife of Indra. Among the peasants, where myth depicts Mae Phosop as just a slighted local deity, she is portrayed as a Thai woman in a Thai-style costume with rice shafts in her hand. Meanwhile, the images of Mae Phosop found in temples are different. In many temples she is depicted as a bare-breasted deva (angel) like the deva of India, who are also represented as bare-breasted women, though she is identified as Mae Phosop (pictures6-7). In some areas where the local god of abundance was male, $P_{0}$ Phosop, the local people adopted the image of the Indian god of abundance, Kuvera, instead of Phosavadheve (pictures4-5).

\section{Po Nagar 20}

Po Nagar was the Goddess Mother of the Cham. In the earliest time, she was a spirit believed to live in trees. Mus mentioned that she is the deity venerated in Nha Trang. Originally, she was a strictly indigenous goddess.

In the process of Indianization, she was transformed into the "feathers" of Bhagavati Uma, the wife of Shiva, carved from a block of black basalt. ${ }^{21}$ Simultaneously, she was bestowed by the Cham with a new title, Bhagavati Kauthareshvari, which means 'the happy one of Kuathara's sovereign.' Mus states that "Sanskrit inscriptions testify to the existence of the [amalgamation] (of the union of Shiva and Parvati, which is generally represented in Indian texts), if not by representation, at least in the ritual of the Goddess Kauthara." This shows, said Mus, that Champa followed Hinduism even in its details. ${ }^{22}$

Nowadays, her name changes from $\mathrm{Yan} P u$ Nagara, as indicated in the old inscriptions, to Po Nagar. Also, she is mostly referred to as Po Nagar, the Lady of the Kingdom. Mus says:

Though having been pushed south of Nha Trang, and nothing of the

\footnotetext{
${ }^{20}$ Po Nagar's story is from two sources, Nguyen The Anh's article. 1995. The Vietnamization of the Cham Deity Po Nagar, p. 42, and Paul Mus. The Religious Ceremonies of Champa, p. 83. Her image is in Picture 11.

${ }^{21}$ Nguyen The Anh. 1995. The Vietnamization of the Cham Deity Po Nagar, op. Cit. A Bergaigne, in p. 42.

22 Mus. 2001. Religious Ceremonies and Superstitions of Champa, p.83.
} 
goddess appears to survive, the Cham have not forgotten their oldest goddess. They always called her Po Nagar, that is, Queen of the Kingdom. And the legend attached to her name no longer evokes Bhagavati, the wife of Shiva. And the goddess returns to her primitive state. ${ }^{23}$

In other words, after being transformed into the image of Shiva's sakti, she was not called Parvati or Uma, but was given a new title: Bhagavati Kauthareshvari. The old Sanskrit inscriptions of the Cham identified her as Yan Pu Nagara, which means Queen of the Kingdom. The inscription by King Sriparameshavara in $\mathrm{AD} 1050$, mentions a hymn to the goddess of Nha Trang, the ancient Bhagavati Kauthareshavari identified with Uma, the wife of Shiva. The hymn was translated by Bergaigne as follows:

Being for the one who is the Lord of what is and what is not, having as true nature the origin of the development of existence on earth...being only one with nonbeing and the being that exists in the world, the primordial virtuality of being and non-being, having as body half the body of Shiva who has the moon as his diadem, having a beautiful body, $O$ thou who are part of Lord...O Happy One, triumph in some way over us who are prostrate before thee, by the magical power, ${ }^{24}$

23 Mus. 2001. Religious Ceremonies and Superstitions of Champa, p.83.

${ }^{24}$ Ibid, p.84.
Not only did the Cham reform her name, but they also changed Po Nagar's myth, which is nothing like that of Bhagavati. Here is the myth that appears in the hymn the Cham dedicated to her:

In the hymn to Po Yang Ino Nagara, it is said that she was born from cloud in the sky and foam of the sea. She had materialized in the shape of a piece of eaglewood floating on top of the waves. She had ninetyseven husbands, among whom $P o$ Yang Amo was the most powerful favorite. She had given birth to thirty-nine daughters, who had become goddesses like their mother. She is the one who had created the earth, eaglewood, and rice. And she animated the sacred fig-tree. ${ }^{25}$

We can see that her myth no longer evokes Bhagavati, the wife of Shiva. "And the goddess has returned to her primitive state. This [implies that she] then is the new local deity. [And] Hinduism is again absorbed by something that it escaped from in India herself." ${ }^{26}$

\section{Wathoudaye ${ }^{27}$ and Mae Thauranii ${ }^{28}$}

\section{${ }^{25}$ The hymn is from Nguyen The Anh, p.42. \\ 26 Mus. 2001. Religious Ceremonies and Superstitions of Champa, p. 83.}

${ }^{27}$ Her source is from Melford E. Spiro's Burmese Supernaturalism; A Study in the Explanation and Reduction of Suffering. Her images in pictures 12-13.

${ }^{28}$ This source comes from an Inventory of NonBuddhist Objects in a Central Thai Village, Pictures12-13. 
These two goddesses are the same. They are earth goddesses. Wathoudaye is the earth goddess of Burmese, while Mae Thauranii, of the Thais.

In Burma, the original supernatural being there is called ' $n a t$.' Meanwhile in Buddhism, supernatural beings are called 'devas.' As imported into Burma, they were classified together with the indigenous Burmese supernatural beings 'nats.' However, the devas were and are differentiated from other nats by being designated as good, or as Buddhist nats, while the indigenous nats were designated as evil.

Spiro states that nats-devas are frequently to be seen on pagoda platforms or in monastic compounds. He also claims that "in fact, nats are only rarely and inconspicuously found in pagoda compounds. With one important exception, the only conspicuous nats to be found in any Buddhist holy place or holy structure in Burma are devas, the Buddhist nats."

The reason why these nats are the only kind that can live in the vicinity of a Buddhist holy place is, according to Spiro, that it has to trace back since the reign of King Anawratha. In adopting the supernatural beings of Buddhism, devas, placing them in the temple area, and then classifying them as a kind of nat, the King hoped to "induce the conventional local people into new religions," which he first introduced into Burma.

The Burmese deva I choose to analyze in the paper is said by Spiro to be the most popular one. Her Indian name is Vasundhara, but as she was a dopted into Burma, the Burmese later inflected the word into the Burmese-sounding word, Wathoudaye, but the meaning is still the same. The new title still means earth goddess in the Burmese language. She also is identified in the Burmese Buddhist myth as the assistant of the Lord Buddha. Here is the myth of Wathoudaye, told by Spiro.

[The earth goddess appeared,] when the embryo Buddha was about to be ousted from his place under the Evil One and his host to fight in the flood of water which she wrung from her hair, wet with libations commemorating the meritorious deeds performed by the future Buddha. ${ }^{29}$

Spiro also mentions that her myth is very similar to that of Mae Thauranii, the Earth mother in Thailand. The reason that the Thais adopted her might be the same as that of Wathoudaye; that is to serve Buddhism.

Her name is unlikely to be the local Thai language. The word "Thauranii" is an Indic word, both in Sanskrit and Bali, meaning earth. However, her name had been adapted by putting the Thai word "Mae" in front, in order to make a local sounding word. Interestingly, like her Burmese version - Wathoudaye - she is depicted as a woman wringing her hair in order to help the Buddha (see pictures12-13).

4. Burmese local female deities: the Golden Face, Lady Three Times Beautiful, and Little Lady ${ }^{30}$

${ }^{29}$ Spiro. 1967. Burmese Supernaturalism; A Study in the Explanation and Reduction of Suffering, pp.45-46.

${ }^{30}$ Their sources come from Maung Htin Aung's Folk Elements in Burmese Buddhism 
These Burmese female deities belong to the group of the thirty-seven nats. The original meaning of the Burmese word ' $n a t$ ' is 'Lord'. The difference between this group of deities, who actually were 'nats', and Wathoudaye, who has also been called ' $n a t$ ' as mentioned earlier, is that the former are the prototype of nats worshipped by the locals long before the advent of Buddhism. On the other hand, Wathoudaye was a new exotic Buddhist Nat. This kind of nat is described by Maung Htin Aung as follows:

There were originally quite ordinary human beings, whose strange and sudden deaths, however, roused feelings of terror and pity in the minds of their contemporaries. $^{31}$

The worship of nats was purely native in origin and developed out of a form of animism. When Anawratha made Theravada Buddhism the national religion of the country, he tried to suppress Natworship. However, as his people went on worshipping the nats, Anawratha finally decided to bring them over into Buddhism.

The figures of the Thirty-six Lords were taken from their shrines and placed in the king's great pagoda in an attitude of worship; he declared that the number was now thirty-seven, because Sakra, the king of the gods and guardian of Buddhism, was at the head of the pantheon... The nats themselves were not shown to be worshippers of the Buddha. ${ }^{32}$

${ }^{31}$ Maung Htin Aung. 1959. Folk Elements in Burmese Buddhism, p.84.
Now let me discuss the story of each deity.

\subsection{The Golden Face}

With her abode on Mount Popa, she is considered one of the most important nats, as described by Maung Htin Aung, the Lady Golden Face was a very beautiful maiden who had a mighty brother. Her brother was so powerful that it was said he could shake the whole city. The king, scared of her brother, raised the girl to be his Queen. Having always desired to get rid of the Queen's almighty brother, the king later invited him to Tagaung. After the mighty man's arrival, the king ordered soldiers to seize and tie him to a Saga tree on the banks of the Irrawaddy. Then, they lit a fire at his feet. Seeing this, the Queen rushed into the fire to die with her brother. The king tried unsuccessfully to save her; he pulled her back by her hair. Though almost all of her body had been burnt, her beautiful face was saved.

As the brother and sister died and became nat spirits, they made their abode on the Saga tree, and they killed all animals and human beings who came under the shade of the tree. This frightened the king so much that he ordered the tree to be cut down and the trunk of the Saga tree floated down the river. The trunk reached the city of Thiripyissaya, the Kingdom of Pagan to-be, where King Thinlikyaung reigned. The king ordered images of the brother and sister carved out of the tree trunk.

\subsection{The Lady Three Times Beautiful ${ }^{33}$}

\footnotetext{
${ }^{32}$ Ibid, p.4.

${ }^{33}$ The Lady Three Times Beautiful and The Little Lady with the Flute are Pyu gods who were
} 
She is the second Pyu Goddess. Muang Htin Aung states that she was a village maiden who was so beautiful that the king, the great Duttabaung, sent a nobleman to fetch her to be crowned queen of Pagan. ${ }^{34}$ Falling in love with Three Times Beautiful on the way, the nobleman came to the King alone and announced that she had a beautiful face, yet her body was so monstrously fat that she could not enter the gates of the city. The King believed him and expelled her to a hut outside the city gates. She dwelt there, forgotten by the king, and forsaken by her lover. She earned her living as a weaver. In time, she gave birth to a little girl and then died of grief and became a nat.

As stated by Maung Htin Aung, she and Golden Face are shown in later wooden figures in the conventional attitude of grief, will right hand on the left breast. ${ }^{35}$

\subsection{The Little Lady with the Flute}

She was the daughter of the Lady Three Times Beautiful. Her story is told by Maung Htin Aung as follows:

[She] is the third Pyu Goddess, the Little Lady, and her name originally meant 'the Little Lady with the Flute'. However, the image at Pagan and later wooden images do not show her playing a flute.

worshipped at Prome and were later worshipped at Pagan.

${ }^{34}$ Maung Htin Aung. 1959. Folk Elements in Burmese Buddhism, p.87.

${ }^{35}$ Ibid, p.88.
Significantly, Maung Htin Aung also describes the process of her transformation.

As Hindu gods, especially

Krishna, a reincarnation of

Vishnu, are often shown playing on a flute, it seems logical to assume that the Little Lady of Prome became merged with an earlier Hindu goddess.

(Maung Htin Aung, pp. 87-88)

By focusing on the first four goddesses, Mae Phosop, Po Nagar, W athoudaye and Mae Thauranii, we c an s ee that there a re some changes in them from the pure Indian materials. The Indian materials were just the locals' first models. Then, these foreign materials were localized in some way (in their names, forms, or myths) in order to make them fit with local statements. This corresponds to what Wolters indicates as "local genius." ${ }^{36}$ It also seems to indicate that the hypothesis of Coedes is inaccurate.

Actually, it doesn't mean that Coedes and his hypothesis are wrong. Indeed, no man's hypothesis is more exact than that of Coedes, if the issue of Indian civilization in ancient Southeast Asian states is under discussion. Po Nagar's image $^{37}$ and her original name, Bhagavati Uma, a re the best examples to show that Coedes was exactly right in this aspect. Indeed, the legacy of Indian civilization in Southeast Asia has been outstanding, and the evidence can obviously be seen with our own eyes even today.

\footnotetext{
${ }^{36}$ Wolter., 1982. History, Culture, and Region in Southeast Asian Perspectives, p.45.

${ }^{37}$ See picture 9.
} 
But it is his hypothesis that "the localized culture, including cultural materials, cannot be far different from its origin", or his other statement "their culture [has] never lost its family resemblance," quite an exaggeration. Here, it has to be reiterated that as time passed, the Indian culture which came to Southeast Asia in the early centuries, was eroded, undermined, as the locals added to it some strange ingredients of their own. In other words, it could be said that the Indian materials, having been adopted into Southeast Asia, had certainly been localized. There is no more exact explanation than that the Southeast Asian states had indeed adapted the exotic materials in order to make them fit with the new environment in Southeast Asia.

However, as demonstrated in the case of the goddesses, we realize that as Wolters notes, the localizing processes have been unequal:

And I suggested that they were "localized" in different ways to become part of the local culture just as Sanskrit loan words were localized, and that Foreign and local statements belonged to what I called "local cultural statements", though the pattern of localization could not be uniform throughout the region. ${ }^{39}$

The question then is why the localization was unequal. To answer this, now let me focus again on the case study in order to

\footnotetext{
${ }^{38}$ See also Wolters. 1982. History, Culture, and Region in Southeast Asian Perspectives, op. Cit. Coedes. in p. 45 .

${ }^{39}$ Ibid., p. 67.
}

see the extent to which the localization was carried out on the Indian materials.

\section{An analysis on the case study: local goddesses}

The case study shows us the inequality of the process of localization on the foreign materials. This might make one doubt the movement of the process. But the explanation is very easy.

Local people had an important role in the process of cultural evolution, as they were the arbiters on whether Indian materials could live or should leave. It was not the Indians who spread the influence, but the local users who would decide whether any Indian materials could live in the local society or not. What happened was that the local people chose only the materials that benefited them. The Indian convention might not be so completely localized if it was useful to them. However, that convention was still more or less localized so that it could fit in the new environment.

In order to make this point clearer, I would like to divide the four goddesses into two main groups, according to the users' purposes. Let us begin with the first group which includes Mae Phosop and Po Nagar.

As I have mentioned, Mae Phosop and Po Nagar were local deities, revered by the local Thai and Tai people since long before the arrival of Indian influence. Mae phosop was the rice mother of the Thai and Tai, and Po Nagar was the Goddess Mother of the Cham. Similarly, both of them were spirits at the earliest time before the coming of Indian influence.

One can imagine that it is hard for man to worship something abstract. But the best 
that Southeast Asians could do at that time was to suppose that their deities abided in nature; the Thai and Tai believed that their deity, as a soul (Khwan), resided in rice or rice shafts, while the Cham believed that their deity resided in earth or trees. When the Indian cultural influence came, the locals made use of it. What they did was to adopt the elaborate Indian materials, which, in this case, were myths, forms, and $\mathrm{n}$ ames to modify their deities. In the other words, they used the Indian materials and conventions as models for developing their deities into more elaborate forms.

"In sum, the local adopters' main purpose was to reify their shapeless deities as it was better to worship something tangible." ${ }^{40}$ Moreover, it might help comfort the local people whose main occupation was farming. By making the deity who protected their rice and thus their lives visible, they could be more secure. Thus, they adopted the Indian forms and images and applied these to their deities. After the purposes were achieved, it seems that the local people no longer realized the importance of Indian materials. These first Indian models were then thrown out of the local cultural orbit. This case corresponds to Wolters' observation:

In some statement [sic], the foreign conventions have retreated so completely that they have come, in a literal sense, decorative. $^{41}$

${ }^{40}$ Mus. 2001. Religious Ceremonies and Superstitions of Champa, p.83.

${ }^{41}$ Wolters. 1982. History, Culture, and Region in Southeast Asian Perspectives, p.63.
On the contrary, what happened to Wathodaye and Mae Thauranii is different. This group actually underwent the same process of reification. However, here this process served a more special purpose.

In Thailand and Burma, the national or main religion is Buddhism. When Buddhism first spread into these two states, both adopted the model of this religion (and surely then localized it). As Buddhists, the people believed in the Buddha's teachings and revered his conduct. Wathoudaye and Mae Thauranii, were introduced in order to boost the Buddha's honor. Moreover, it might be interpreted that, the main purpose of the local adopters, probably the elite rulers, in introducing them into the societies, was to teach the local subjects good morals. The earth goddess' wringing her hair to protect the Buddha from Mara can teach that the good, moral person cannot be destroyed by the evil one as there is some divine, supernatural being protecting him.

Therefore, the old typical Indian conventions of the two goddesses were not changed, as they were still useful to the local population; their myths helped keep the peace in both countries. When the local people heard or saw the images and legends of the two goddesses, they would refrain from d oing s omething bad, o ut of fear of being destroyed as Mara was. However, each state still adapted these deities' names in order to make them harmonious with their society. In Burma, the original Indian name, Vasudhara, was adapted into Wathoudaye; in Thailand, though retaining the Indic name 'Thauranii', the Thais added the Thai word 'Mae', in order to make her more 'Thai'. 
This means that though these goddesses were pure Indian materials, the local people adopted them and then added some local ingredients. The two correspond to the case described by Mus, as cited in Mabbett: "(Mus) sees two levels of culture that lived in each other and were not consciously distinguished."

Things seem to be more complicated in the case of the other three Burmese deities, the Golden Face, the Lady Three Times Beautiful, and the Little Lady. In one way, these three goddesses are similar to the first group discussed earlier and in another they are similar to the second. On the one hand, their cases are like those of Po Nagar of the Cham, and of Mae Phosop of the Thais. Not only were their origins purely local, not Indian, but the three of them w ere a lso a ctually the spirits of the dead, believed to abide in nature. The Golden Face, for instance, was supposed to reside in the Saga tree. This really differentiated then from Wathoudaya and Mae Phosop, who were actually the same deity, and adapted forms of the Indian Goddess, Vasundhara.

Nevertheless, on the other hand, these three goddesses are similar to Wathoudaye and Mae Phosop as they were also affected by King Anawratha's attempt to make Theravada Buddhism the new religion of his state. As Animism was so influential and had deep roots in the people's mind, the king in his attempt to convert his people, adapted the influential supernatural beings to the new exotic religion. Thus, their cases also correspond to that of Wathoudaye and Mae Thauranii and thus the theory of Mus and Mabbett.

Interestingly, each goddess in her numerous different images, points to the inequality of the localizing process. This can be perfectly illustrated in the case of Mae Phosop, whose image can frequently be found in Thailand.

Often, we see various differences in Mae Phosop's images. In a mural in the Throne Hall at the Royal Palace, Phaisan-Thaksin, her image is drawn in the traditional Thai style as a deva who wears a Thai-style headdress and a Thai royal golden sash, but is bare-breasted like an Indian deva (Pictures6-7). Meanwhile, some images of Mae Phosop, seen in some posters or pictures in rural areas, are not at all similar to an Indian goddess, but show a pretty Thai woman in a Thai style costume. Here, Mae Phosop bears no resemblance at all to the old form of an Indian goddess. Phraya Anumanrajadhon even observed that, "Mae Phosop (in Thai society today) is not an Indian goddess at all, for she is represented as a woman in a Thai costume with a Thai hair style and rice shafts in her hand." ${ }^{, 2}$ (Picture8)

The reason for these variations is that in earlier times, the local people in each Southeast Asian state could be roughly divided into two main classes: the elite and the commoners. Each class had its own purpose in adopting Indian materials as their own. This then, explains why cultural materials adopted from India have retained different degrees of Indian influence.

The elite may have adopted exotic, sacredlooking $m$ aterials in order to differentiate themselves from the masses. They wanted to make themselves better than the common people, and they were probably able to do this as their knowledge of

\footnotetext{
${ }^{42}$ Wanna Nawigamoon. 2001. "Trace back Mae Phosop", op. cit. P hraya Anuman Rajadhon. in p.36.
} 
Indian conventions and arts was so much better than that of the uneducated masses. Thus, the Indian materials they adopted were usually changed less than, this those adopted by the common people. This can be seen is the case of Po Nagar. In Picture 9 , we can see that there is a strong Indian influence in her image. This was probably because she was sculpted by order of the elite rulers who considered her and wanted to be considered themselves as divine. Therefore, she had to appear divine and sacred.

The local people, in contrast, may have adopted the exotic materials for less complex purposes. This can be seen in the case of Mae Phosop. The Tai people already believed in supernatural beings, but the Khwan or spirit was, as Mus says, "by nature inconsistent and difficult to grasp."43

The Indian materials and conventions, such as the idea of reification, became tools serving the peasants' purpose. The peasants, whose crops, especially rice, were essential for their survival, might have felt comforted by deities whose existence they can perceive.

For the local common people, the goddess means only the deity who protects them and their crops from changeable and unpredictable nature. In this case, the luxurious Indian-style costumes and embellishments, while were too subtle for them to understand, and while also seemed too extravagant, were irrelevant to their modest purposes.

\footnotetext{
43 Mus. 2001. Religious Ceremonies and Superstitions of Champa, p.84.
}

The Indian materials that did not originate in Southeast Asia, but were adopted in order to serve some purpose of local users might be localized in different ways. Wathoudaye and Mae Thauranii were adopted to serve a Buddhist purpose, so their main functions and postures are unchanged; they have to be sculpted in the hair-wringing pose. Even so, there are still changes in them. In Mae Thauranii' $\mathrm{s}$ case, though local Thai farmers adopted her image and used it in their agricultural lives, as in Yantra, or cabalistic writing, and ancient books about agricultural rituals and traditions, the local Thai artists adapted her typical image by depicting her as riding a turtle (Picture 13).

Interestingly, it is not only in the goddesses' image that we can see the localization process work, one can also see it in the rituals the local people perform to them.

In Mae Thauranii's case, the ritual the local people perform to her today cannot be seen in India. In Thai society, Thai Buddhists have a special ceremony for Mae Thauranii. "In the temple, she receives support in one or more sudra-type sermons that the Buddhist villagers are likely to hear. Moreover, they tend to extend their merit to her during the water Examination. They believe that they can entrust some of their merit to Mae Thauranii for safe-keeping, and then draw on this stock of merit later on. This belief might come from the legend associated with her." 44 Meanwhile, in their agricultural rituals, she is associated with the peasants. When they perform the various rites at the start of the annual rice

${ }^{44}$ Textor. 1960 . An Inventory of Non-Buddhist
objects in a central Thai village. p. 480 . 
cycle, such as Plowing ritual, the Thais are likely to inform Mae Thauranii, along with several other supernatural beings.

From all that I have shown we can see that Mabbeth's view and Wolters' view can be used in different cases and under different conditions. Wolters' view applies in the case of Mae Phosop and Po Nagar, while Mabbeth's view is relevant to Wathoundaye and Mae Thauranii. From these, we clearly see that there are differences among the Indian cultural characteristics left in the local goddesses and, thus, inequality in the localizing processes at work. As I have stated, all this depends on the local adopters only.

\section{Conclusion}

In light of all information I have presented, it is not fair to equate the civilizations of Southeast Asia with "Indianization". The fact is that, in the whole process, Indianization is just the first step of a long journey. The Indian materials were changed by local people, day by day, little by little. First, they were selected by the local adopters. While some materials were adopted, the others were eradicated from the local scene.

The remaining Indian materials continued along the path of localization. During the journey, they were kneaded and molded till they suited the local users' purposes. Luckily, their voyage didn't occur only among the elite, but also expanded to the common people. Their route among the royal elite was likely smooth and easy, as these people wanted to adopt exotic materials only to differentiate themselves from the common people.

However, when those Indian materials came into the hand of the common local people, they adapted them to serve their modest purposes. Such a process happened so many times that the Indian influence left on the materials become less and less.

Even objects where the Indian influence was particularly strong, were localized and retreated into the local statement. Though the process was not so complete, the object had to be changed so that it could live in harmony with the local society without inconsistency or contradiction.

Thus, one can see that the Southeast Asian states possessed their own cultural identities. Even within the region, states were different, and though they all adopted culture from India, their individual genius caused them to localize the foreign culture in their own way, creating, as Wolters put it, a "cultural mosaic."

\section{Illustrations}

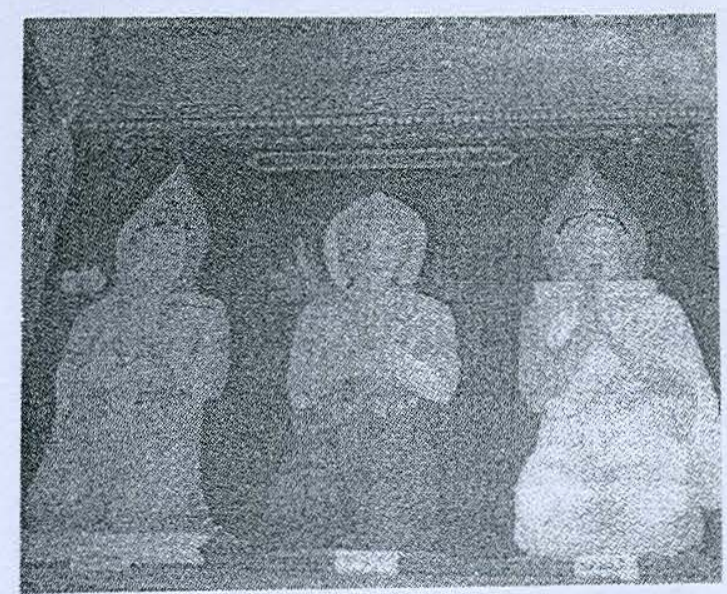

Picture 1: Mae Phosop is sitting between Laksmi and Srasrati. The picture comes from Wat Sam Kaew in Chum-porn province.

\footnotetext{
${ }^{45}$ Wolters. 1982. History, Culture, and Region in Southeast Asian Perspectives, p.55.
} 


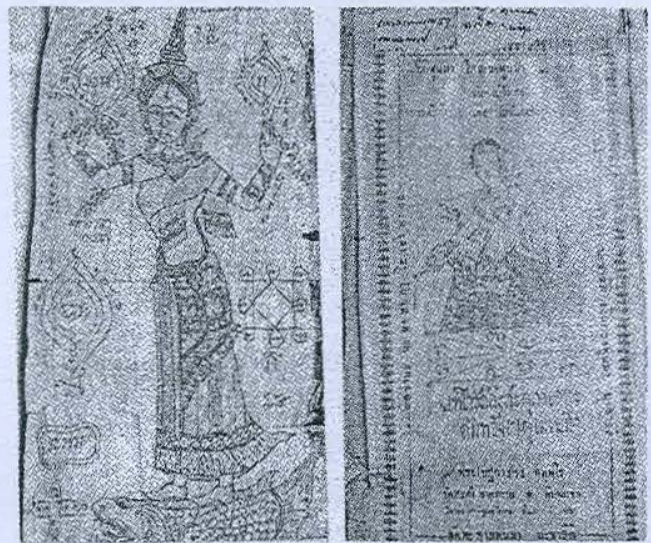

Pictures 2-3: The images of Mae Phosop in capalistic writing, Yantra. In these two pictures, we can see the difference in detail between the two images. In the left picture, Mae Phosop is riding a fish, while in the right picture, Mae Phosop is pouring water from a conch.

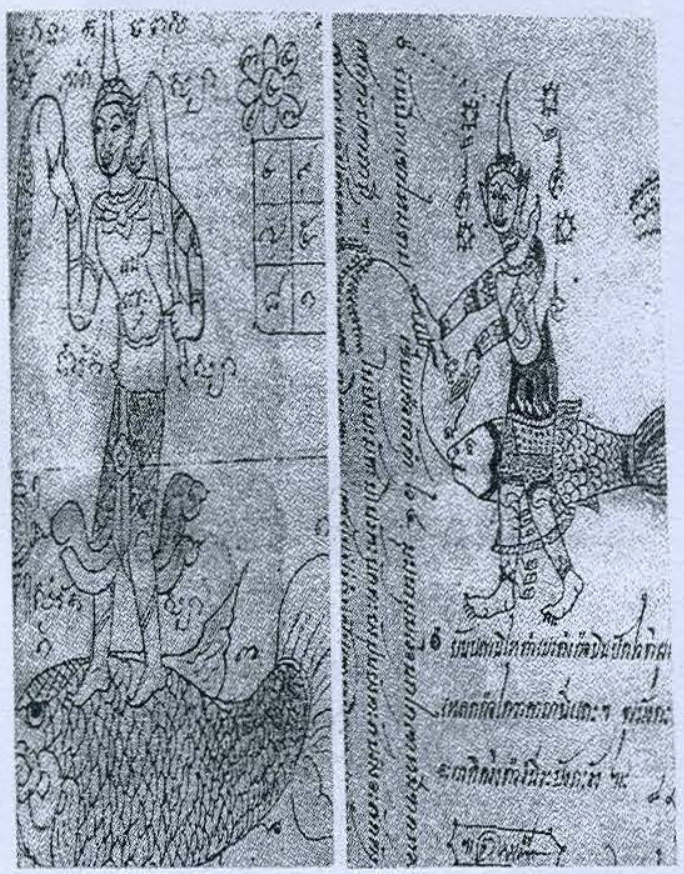

Pictures 4-5: These two images of rice deity are Pra Phosop. The difference between the two picture is Po Phosop (male), while the forth picture is Mae Phosop (female).
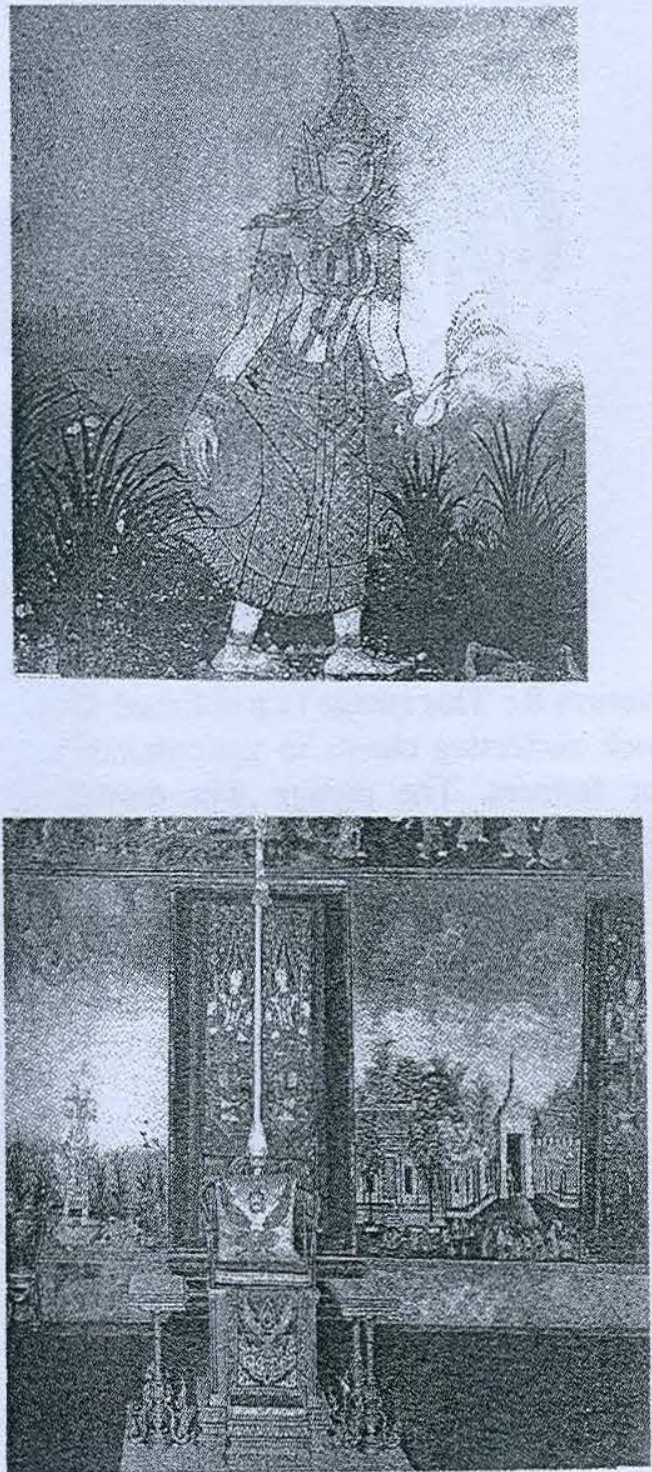

Pictures 6-7: The image of Mae Phosop in a mural at the Throne Hall, Phiasan Thaksin, in the Royal Palace in Thailand. The picture was drawn the royal artist in the reign of King Rama III. Mae Phosop is drawn as a brest-naked devi. 


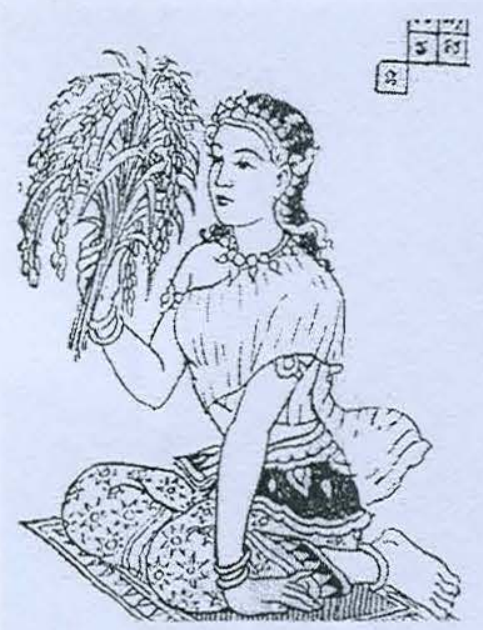

Picture 8: This i mage is published in the book collecting chants in agricultural $r$ ites for farmers. The picture was drawn by well-known local artist, Ard Aud-Umphao in 1932.
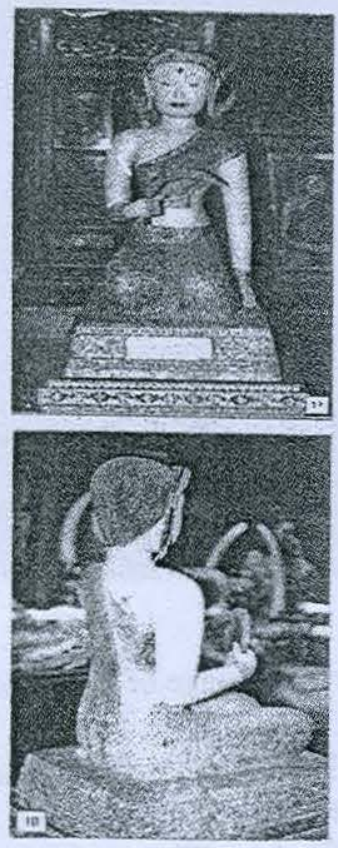

Pictures 9-10: The most distinguished image of Mae Phosop. The statue shows the complete change in The image of Mae Phosop. She doesn't hold rice shafts, but hold a scythe instead.Moreover, her hair style showed the Thai woman's popular hair style in the earlier Chakri Dynasty.

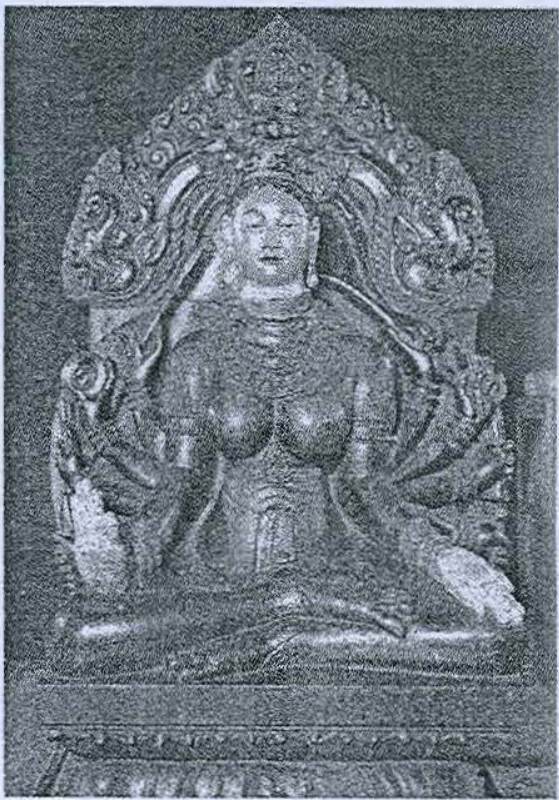

Picture 11: Po Nagar of the trang (Khan Hoa), trakie style $10^{\text {th }}$ century. Her original need was destroyed long time ago. The head in the picture has been replaced at a much late date. Po Nagar today was again localized (Vietnamized) Besides the Vietnamese-styled head, her cloth and ornament is Vietnamese style. 


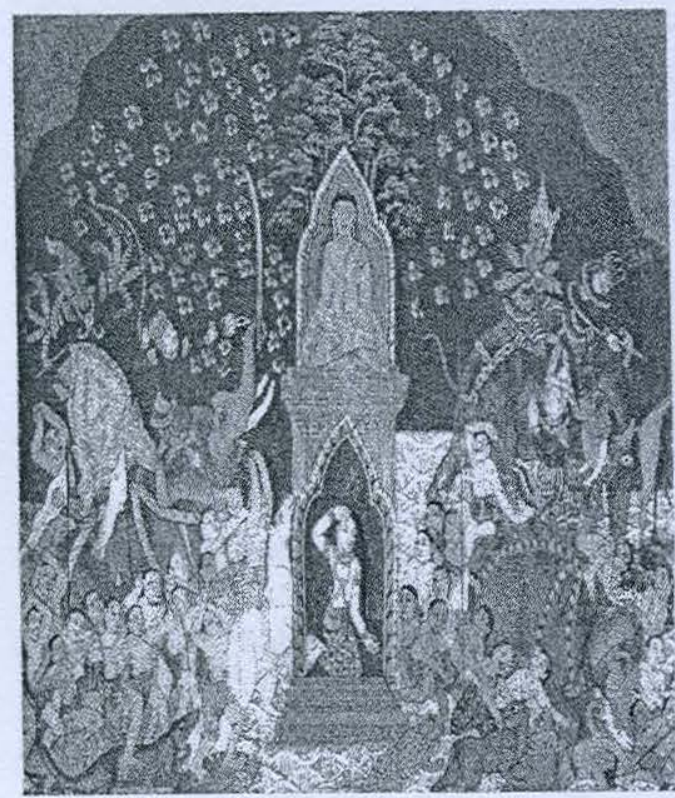

Picture 12: Wathoudaye, earth goddess, in a mural in Buddhist temple, Burma. Like Mae Thauranii, she is wringing her hair in purpose to prevent Buddha from Mara.

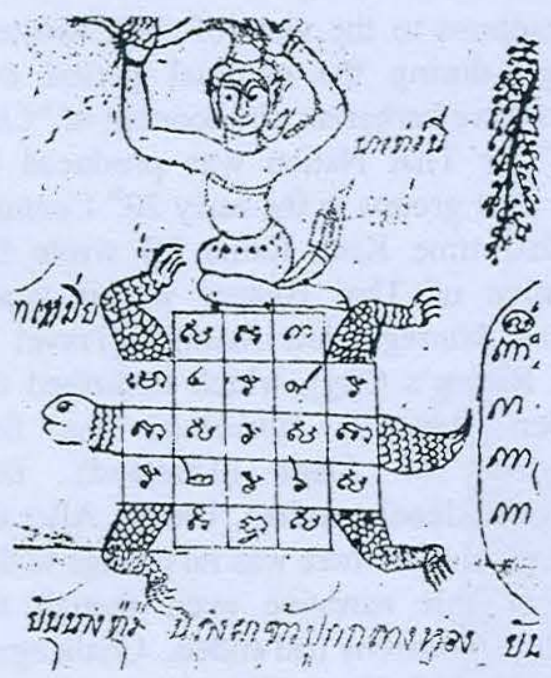

Picture13: Mae Thauranii's image in Thai Yantra. Such a Yantra was founded in farmer's house in Thailand. The Yantra is believed by the local farmers that it help reserving their rice.

\section{References}

Coedes, George. 1968. The Indianized states of Southeast Asia. Honolulu: East-West Center Press.

Mabbeth, I.W. 1978. Kingship at Angkor, Journal of the Siam Society 66, no.2.

Mabbeth, I.W. "The Indianization of Southeast Asia: Reflections on Historical Sources". Journal of Southeast Asian Studies

Maung Htin Aung. 1959. Folk Elements in Burmese Buddhism. White Lotus.

Mus, Paul. and Aymonier, Etienne. 2001. Religious Ceremonies and Superstitions of Champa. Bangkok: White Lotus Press.

Nguyen The Anh. 1995. "The Vietnamization of the Cham Deity Po Nagar". Essays into Vietnamese Parts, Cornell Southeast Asia.

Spiro, M.E. $1967 . \quad$ Burmese Supernaturalism: A Study in the Explanation and Reduction of suffering. New Jersey: Englewood Cliffs.

Textor, Robert B. 1960. An Inventory of Non-Buddhist Objects in a Central Thai Village. Ann Arbor: Cornell University.

Wanna Nawigamoon. 2001. "Trace back Mae Phosop", in Rice in Thai arts and Cultures. Bangkok: Thai Rice Foundation.

Wolters, O.W. 1982. History, Culture, and Region in Southeast Asian Perspectives. Singapore: Institute of Southeast Asia Studies. 